\title{
Investigation into Damaged Gear of Off-Road Motorcycles
}

\author{
Dagmar Bublíková, Hana Jirková, Kateřina Rubešová, Zbyněk Bunda \\ University of West Bohemia, RTI-Regional Technological Institute, Univerzitní 22, CZ - 30614 Pilsen, Czech \\ Republic, e-mail: dagmar.bublikova@seznam.cz
}

If failure occurs in gear wheels in a racer motorcycle gearbox, the possible causes are manifold: inadequate material, improper care (poor lubrication, incorrect assembly) or inadequate thermochemical treatment procedure. This investigation focused on spur wheels of chromium-nickel Czech Standard (ČSN) 16720 steel containing $0.18 \% \mathrm{C}, 0.4 \% \mathrm{Mn}, 1.5 \% \mathrm{Cr}, 4.25 \% \mathrm{Ni}$ and $1 \% \mathrm{~W}$. The steel had been quenched to 60-62 HRC and the case hardening depth was $0.8 \mathrm{~mm}$. The client requested that these wheels have a life of 100 hours. The failure occurred while the wheels were in operation. The fracture surfaces in the wheels were examined in a scanning electron microscope (SEM). The fracture surfaces were prominent in the failure locations. EDS point analysis in the SEM revealed spots with higher chromium levels on the fracture surfaces. The average size of these spots was several dozen micrometres. The spots were suspected to have caused or contributed to the failure. A hardness profile across one tooth was measured using a microhardness tester. In addition, the thickness of the carburized layer was determined. Quality of the surface was assessed using macrophotographs taken with a low-power stereomicroscope. In addition, metallographic sections were prepared and observed in a scanning electron microscope (SEM) and light microscope.

Keywords: Q\&P process, retained austenite, AHSS steels, X-ray diffraction, thermomechanical simulator

\section{Introduction}

Typically, gear wheels are manufactured of carburizing steels with low carbon levels, up to $0.2 \%$. The choice of the steel grade is dictated by the required surface hardness and the core strength for subsequent heat treatment. Heavy-duty gear wheels are made of chromium-nickel carburizing steels. Additions of chromium, nickel and manganese improve hardenability and mechanical properties throughout the crosssection [1]. Chromium and tungsten form carbides which improve wear resistance. The prerequisite for improved hardenability, however, is that the carbides are dissolved upon austenitizing [2]. Nickel and manganese are austenite-forming elements which also contribute to better mechanical properties. Manganese is more effective in improving hardenability in solid solution than nickel. Yet, manganese content should not be too high because that would cause undesirable carbides to form $[3,4,5]$.

Since gear wheels are subjected to severe loads, the purpose of their treatment is to increase hardness and wear resistance of their surfaced. Case hardening is one of available thermochemical treatment methods for this. It involves carburization of the steel's surface by diffusion. The procedure is carried out above the $\mathrm{A}_{\mathrm{c} 3}$, at approximately $910-930^{\circ} \mathrm{C}$, in gas, liquid or solid media (Fig. 1), [1, 6].

The required carburized depth depends on the loads on the part. Normally it is under $1 \mathrm{~mm}$, and rarely more. The rate of growth of the carburized layer strongly depends on alloying elements which are present in the steel. Carbide formers (Mn, Mo, V, W and $\mathrm{Cr}$ ) reduce the carbon diffusion coefficient, and thereby lower the diffusion rate. On the other hand, they form carbides, and thereby increase carbon content in the surface layer. The element which increases the carbon content the most is chromium. Non-carbide formers $(\mathrm{Si}, \mathrm{Ni})$ reduce the carbon content and impede diffusion within the surface layer [7].

The content and distribution of carbon in the carburized layer depend on the carburizing medium. The optimal carbon concentration in the layer is $0.75-1.1$ $\%$ which is close to the eutectoid level (Fig. 1). The carburized layer comprises a hypereutectoid (with secondary cementite and pearlite), eutectoid, and hypoeutectoid (pearlite and ferrite) zones. At higher carbon concentrations in the layer, the bending strength and strength in torsion, impact notch toughness and fatigue strength of the material are reduced. The possible reason is formation of hypereutectoid carbides which pose a risk if present on grain boundaries. The secondary cementite network which forms along austenite grain boundaries on cooling impairs mechanical properties and may lead to gear teeth failure [8].

The failure may take different forms: brittle fracture (fatigue failure at the bottom of the tooth), surface fatigue on tooth face (pitting, crumbling away), abrasive wear, seizing (formation of welds and their separation). Its causes may include overloading due to 
static indeterminacy (inaccurate manufacture and assembly may result in contact being present in only part of the width), errors in production routes (thermochemical treatment failing to deliver the desired properties), poor discipline of the operator (incorrect lubrication, poor-quality assembly) or incorrect thermochemical treatment procedures [9].

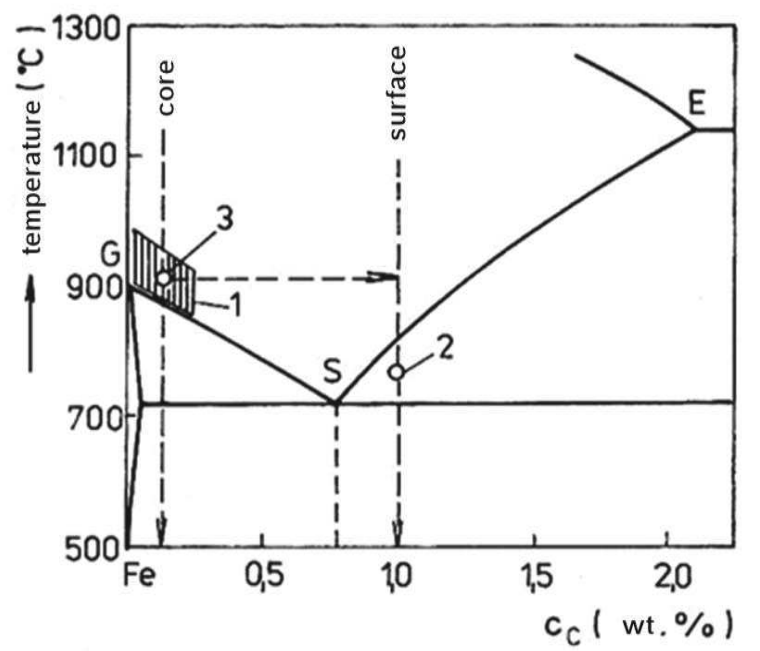

Fig. 1 Schematic illustration of the carburizing process in the $\mathrm{Fe}-\mathrm{Fe} 3 \mathrm{C}$ equilibrium diagram [10]

\section{Materials and methods}

The gear wheels supplied for examination were made of chromium-nickel Czech Standard (ČSN) 16720 steel. They had two different diameters and were part of a gearbox of an off-road motorcycle (Fig. 2). The smaller addendum circle had a diameter of $50 \mathrm{~mm}$ and the related tooth height was $6.4 \mathrm{~mm}$. The larger addendum circle was $53 \mathrm{~mm}$ in diameter and the tooth height was $5.9 \mathrm{~mm}$. Chemical composition of the steel is given in Table 1 . The gear teeth were carburized to a depth of $0.8 \mathrm{~mm}$ and hardened to 60-62 HRC. For the wheels the client required a life of 100 hours. The goal of the investigation was to identify the cause of the in-service failure in the wheels.

First, the fracture surfaces in the wheels were examined in Tescan Vega 3 scanning electron microscope. To assess the surface quality, a macrophotograph was taken using Olympus SZ 61 low-power stereomicroscope. For the purpose of comprehensive characterization of the material, metallographic sections were prepared and examined. They were observed in the scanning electron microscope and under Olympus GX 51 light microscope. Hardness profile across a tooth with carburized layer was measured by means of Vickers UHL VMHT microhardness tester.

Tab. 1 Chemical compositions of experimental steel AHSS [wt. $\%]$

\begin{tabular}{|c|c|c|c|c|}
\hline $\mathrm{C}$ & $\mathrm{Mn}$ & $\mathrm{Cr}$ & $\mathrm{Ni}$ & $\mathrm{W}$ \\
\hline 0.18 & 0.4 & 1.5 & 4.25 & 1 \\
\hline
\end{tabular}

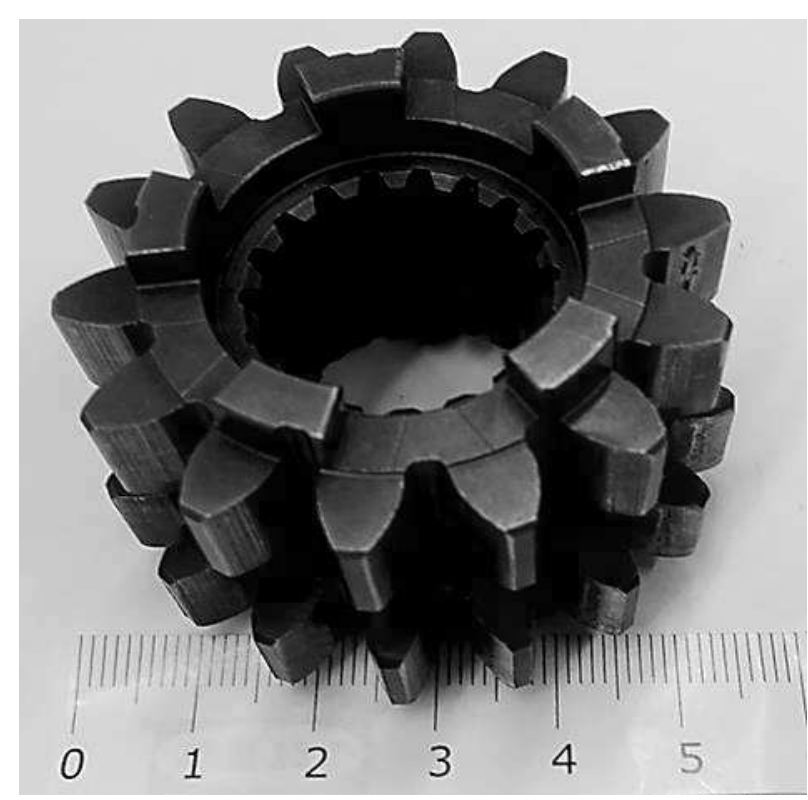

Fig. 2 Gear wheel from an off-road motorcycle

\section{Discussion of results}

Fracture surfaces in the damaged gear wheel were examined using electron microscopy. The fracture was of mixed nature: ductile fracture with dimples and a certain proportion of brittle phase (Fig. 3, Fig. 4). The fracture surfaces contained visible cracks caused by overloading (Fig. 5). In addition, there were spots in which chromium content was higher than elsewhere. Their average size was several dozen micrometres (Fig. 6). This was confirmed by point analysis using EDX (Fig. 7). These might have caused or contributed to the failure.

To assess the quality of surface of one of the gear wheels, a macrophotograph of its tooth was taken using a low-power stereomicroscope. The surface shows marks from machining (Fig. 8).

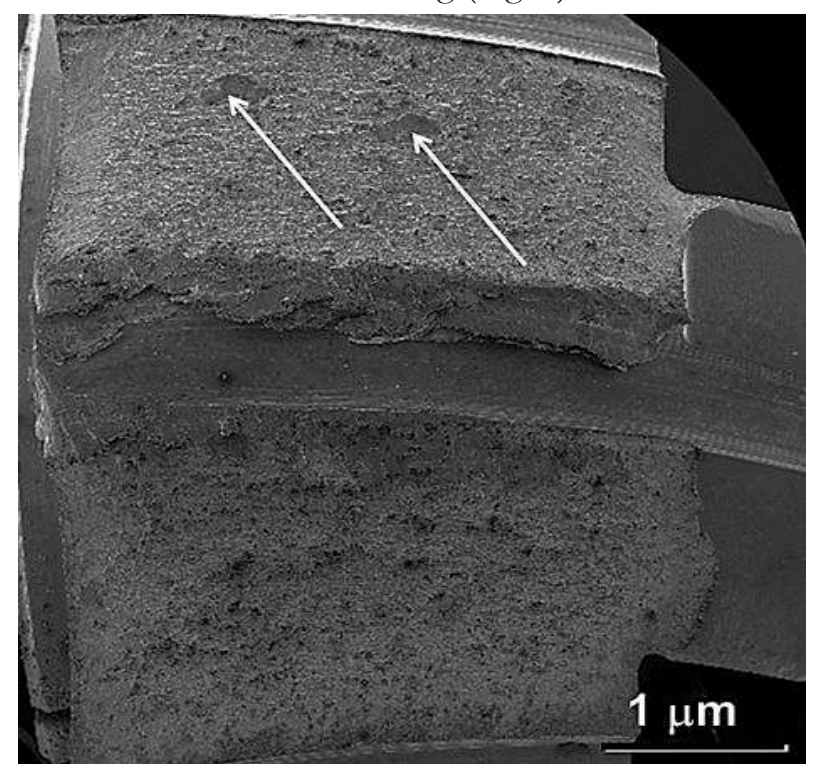

Fig. 3 General view of fracture surface with brittle fracture regions 




Fig. 4 Mixed fracture surface with steps

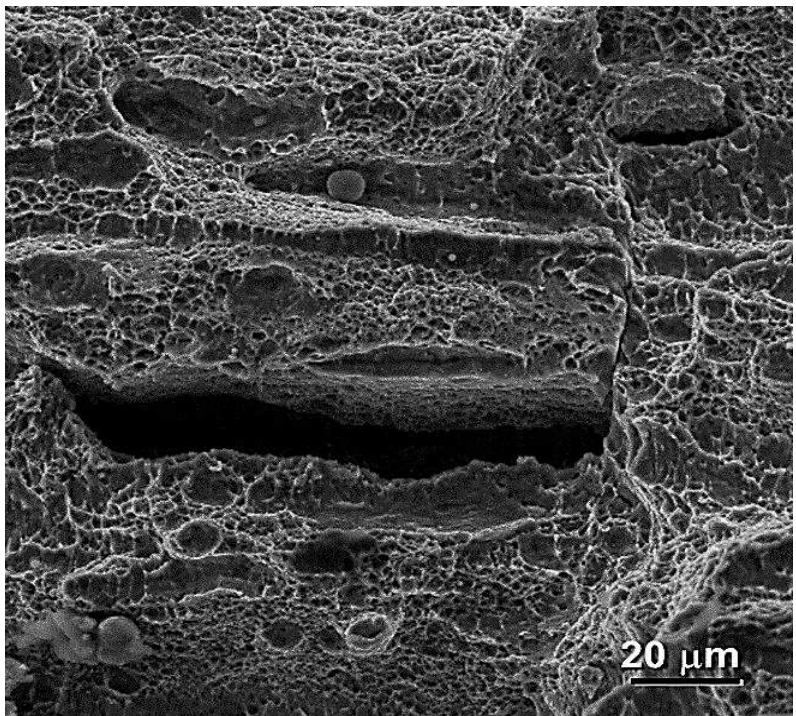

Fig. 5 Detail of surface created by in-service failure due to overloading

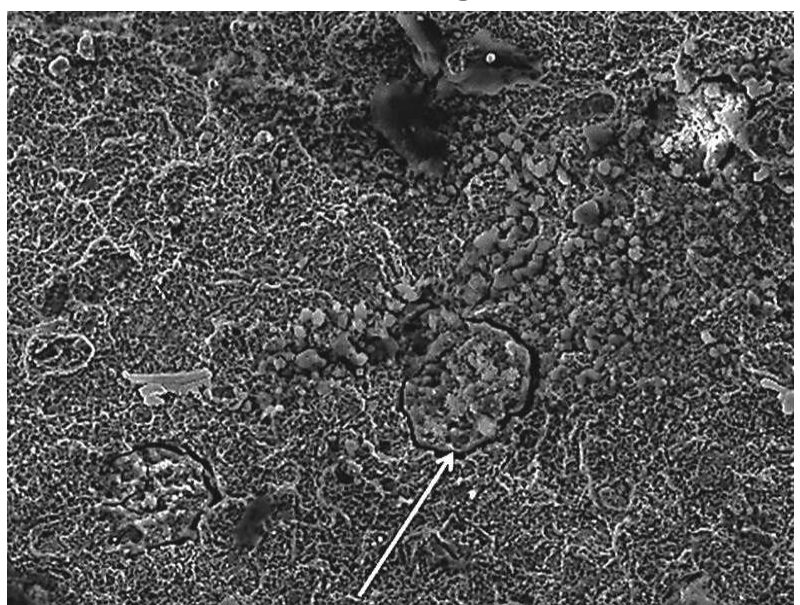

spots with increased chromium levels

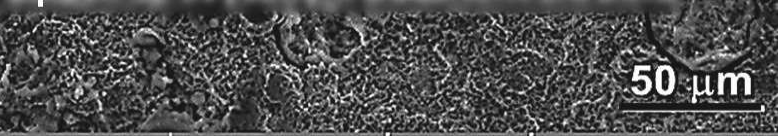

Fig. 6 Spots with increased chromium content

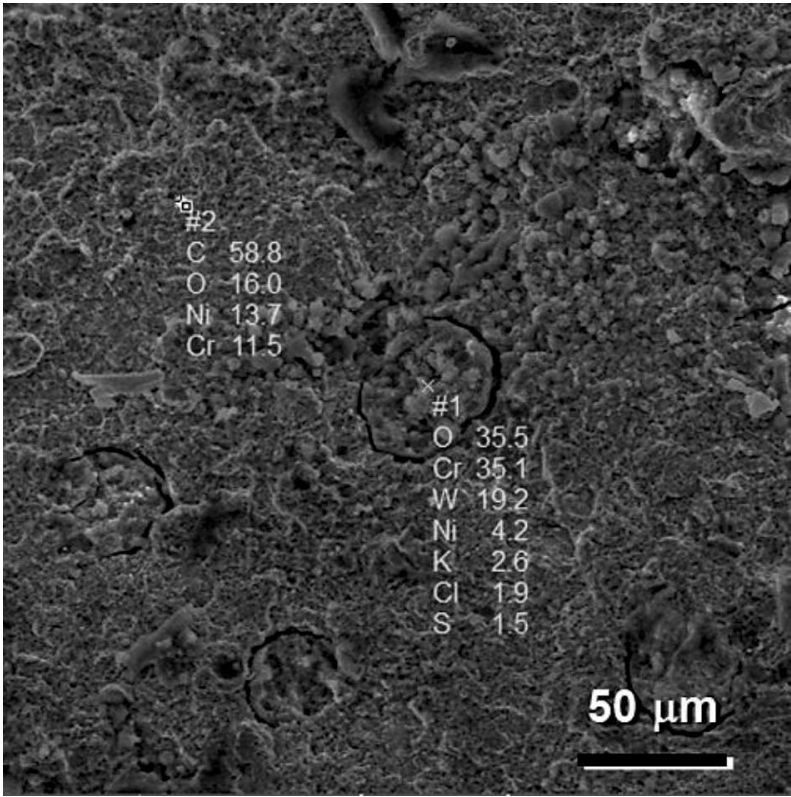

Fig. 7 Spots with increased chromium content - EDX analysis

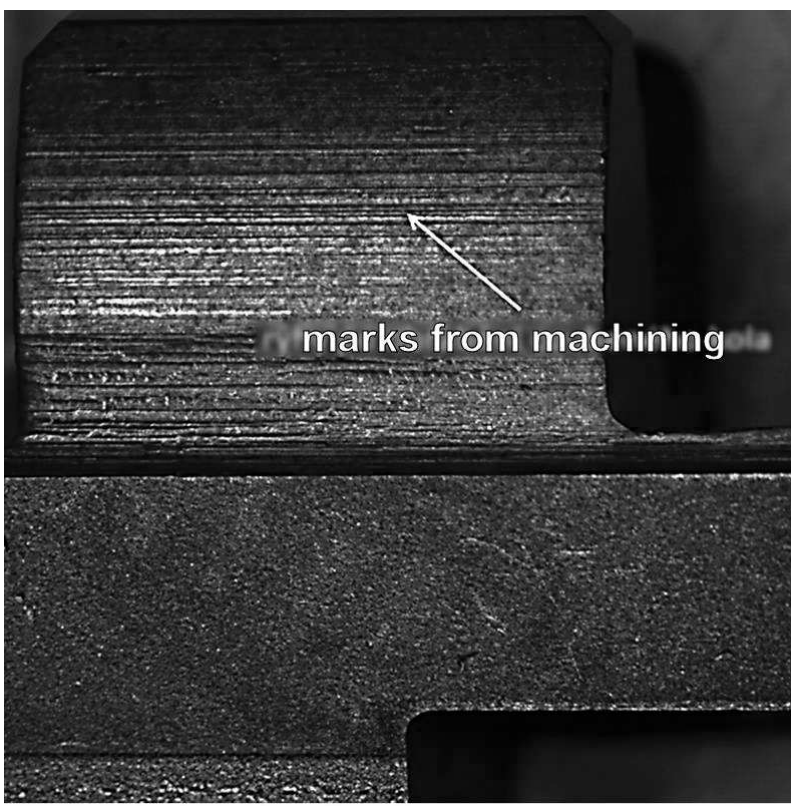

Fig. 8 Tooth face surface

For the purpose of comprehensive characterization of the material, metallographic analysis was performed. The macrophotograph of a metallographic section shows the carburized layer on the surface (Fig. 9). A scanning electron micrograph of metallographic section through an intact gear wheel tooth (Fig. 10) shows long cracks which spread from the bottom of the tooth across the carburized layer all the way into the base material (Fig. 11). Smaller cracks and carbide network along prior austenite grain boundaries were found in the top of the tooth and in its core (Fig. 12).

Under a light microscope, uniform mostly bainitic microstructure with a small amount of bainitic was identified (Fig. 13). This was confirmed by observation in a scanning electron microscope (Fig. 14) and 
hardness data. The hardness of the gear wheel core was 444 HV10.

The metallographic section through a fracture surface of the wheel which failed in service showed cracks and carbide network along prior austenite grain boundaries. The latter was probably formed due to improper carburizing and super-saturation of the surface with carbon (Fig. 15). The carbon content should be around the eutectoid concentration (Fig. 1).

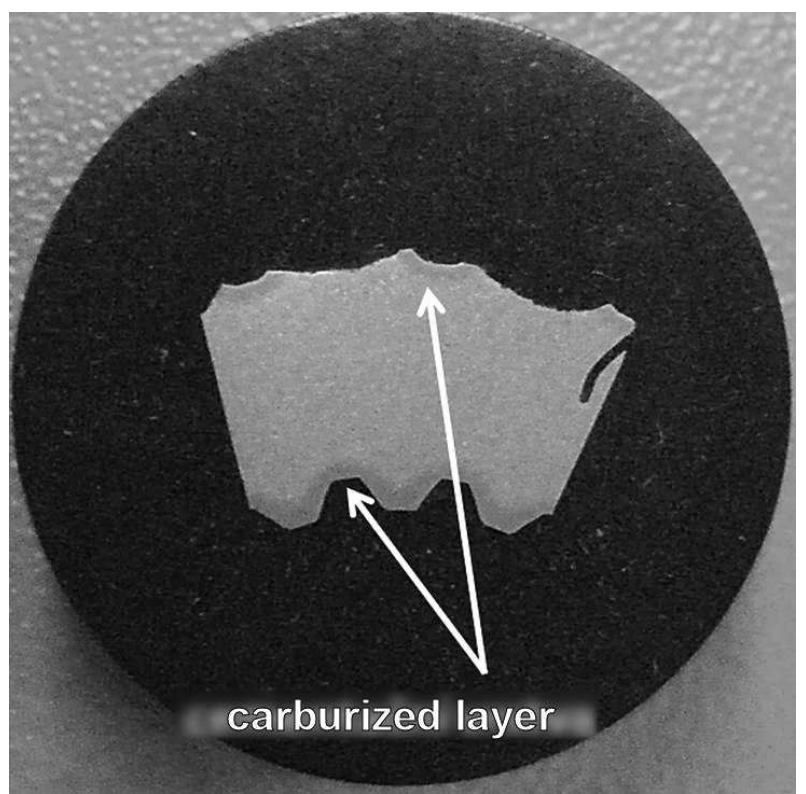

Fig. 9Metallographic section showing the carburized layer

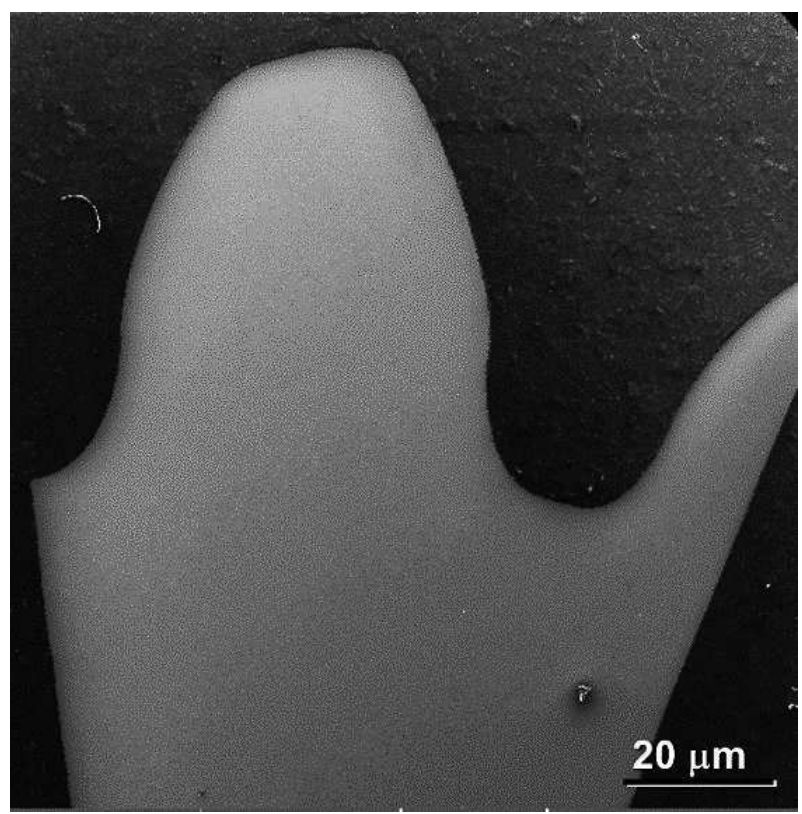

Fig. 10 Metallographic section through an intact tooth

Hardness profile across the tooth was measured using a microhardness tester. Fig. 16 shows the depth profile of microhardness HV0.1 from the tooth face. This hardness profile suggests that the carburized layer depth is in line with the manufacturer specifications, i.e. approx. $0.8 \mathrm{~mm}$.

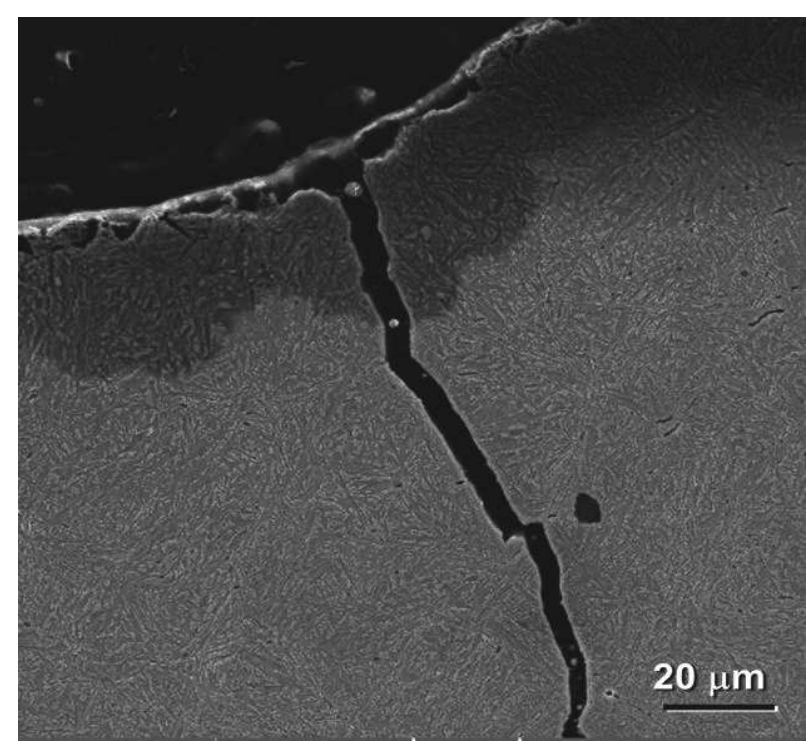

Fig. 11 Crack in the bottom of a tooth - scanning electron micrograph



Fig. 12 Microstructure in the top of a tooth, carburized region with carbide network - scanning electron micrograph

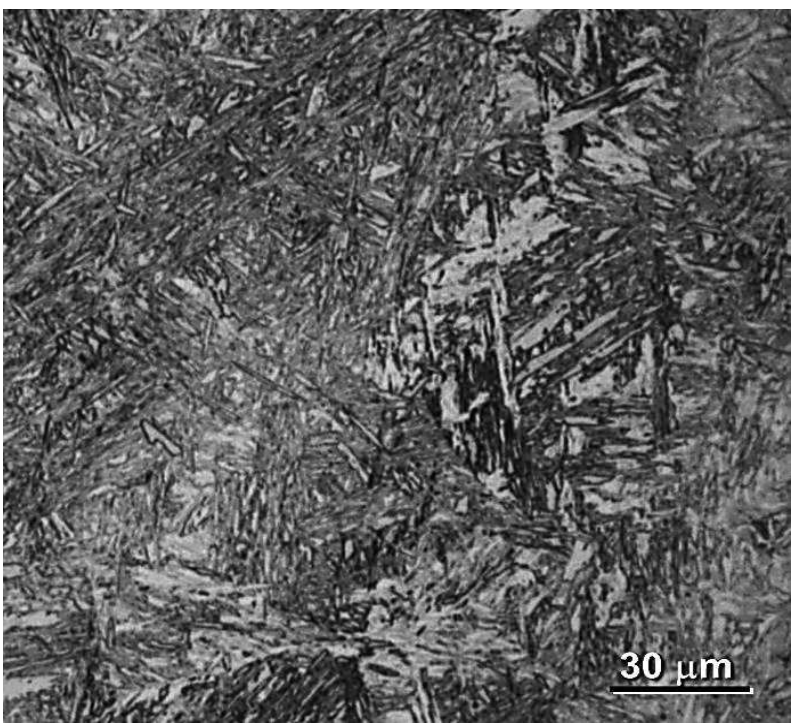

Fig. 13 Bainitic-martensitic microstructure, light micrograph 


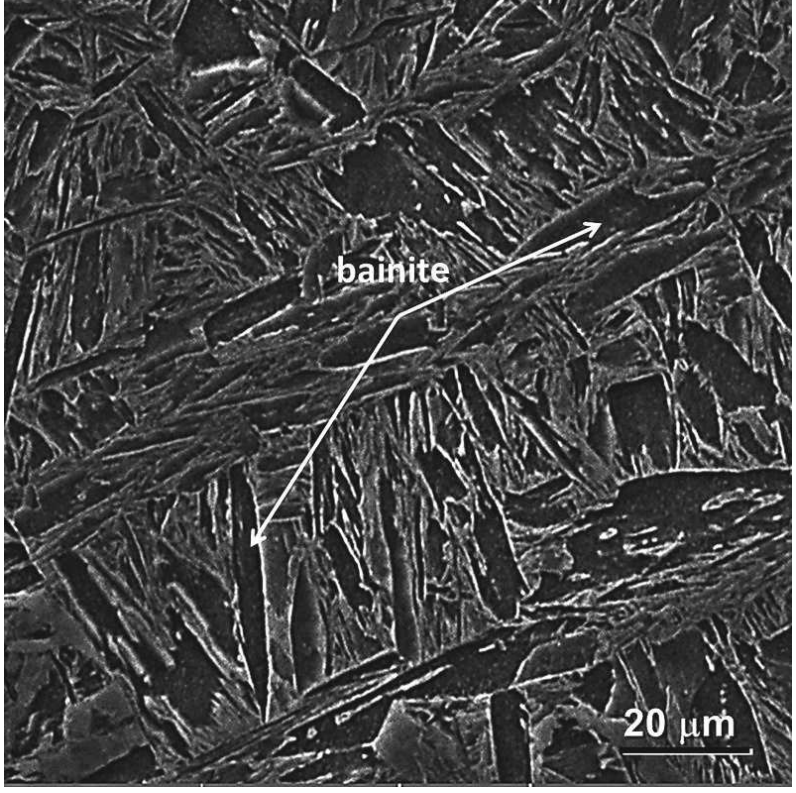

Fig. 14 Bainitic-martensitic microstructure, scanning electron micrograph

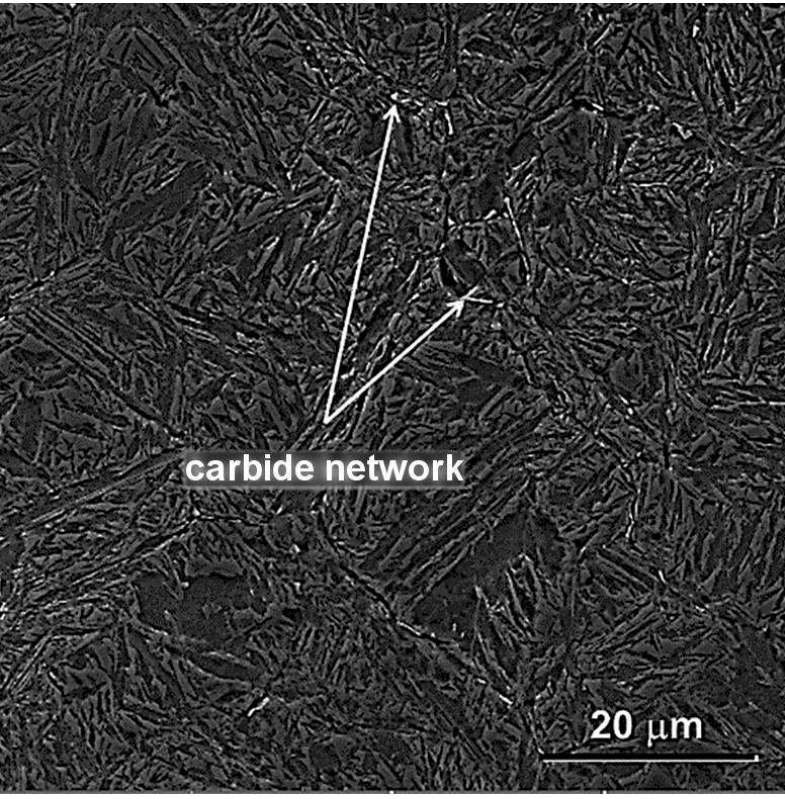

Fig. 15 Microstructure below the fracture surface in a tooth; carbide network is present

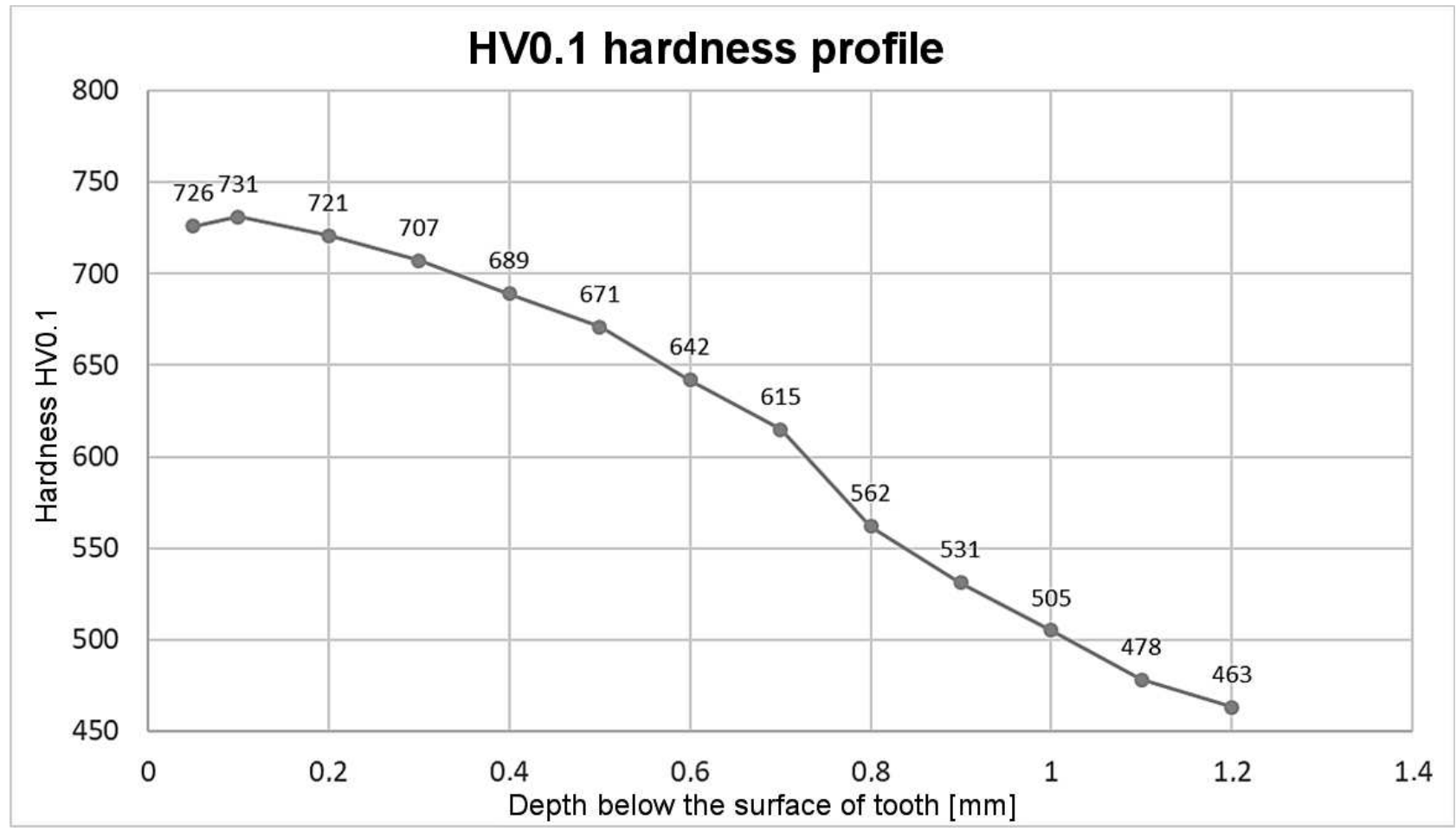

Fig. 16 Hardness profile in the tooth

\section{Conclusion}

Failed gear wheels from off-road motorcycles made of ČSN 16720 chromium-nickel steel with a carburized layer of $0.8 \mathrm{~mm}$ were examined using metallographic techniques. It was found that the likely cause of the failure was improper carburizing conditions. Carbide network developed in the microstructure as a consequence of super-saturation of the surface layer with carbon. Carbon concentration exceeded the solubility of carbon in austenite which is indicated by the
$\mathrm{A}_{\mathrm{cm}}$ curve in $\mathrm{Fe}-\mathrm{Fe}_{3} \mathrm{C}$ equilibrium diagram. As a consequence, cementite formed along grain boundaries in the course of carburizing. This cementite remained present after quenching, causing brittleness and, most likely, the failure. It is possible that stresses caused by quenching led to defects immediately.

Another factor which might have contributed to failure was the poor quality of the gear wheel surface in the most-severely stressed region at the bottom of teeth. The surface of teeth contain scratches which act as stress concentrators under load. 


\section{Acknowledgements}

The present contribution has been prepared under project LO1502 'Development of the Regional Technological Institute' under the auspices of the National Sustainability Programme I of the Ministry of Education of the Czech Republic aimed to support research, experimental development and innovation.

\section{References}

[1] SKALOVÁ, J., KOUTSKÝ, J., MOTYČKA, V. (2000). Nauka o materiálech, Vol. 232, pp. 123-133, Západočeská univerzita, Plzeň.

[2] ŠVEC, M., VODIČKOVÁ, V., KELLER, V., HANUS, P. (2018). The Effect of Chromium Addition and Heat Treatment on Phase Composition of Č́st FeAlSi Alloys, Manufacturing Technology, Vol. 18, No. 6, pp. 1029-1033.

[3] BAIK, D., JIRKOVÁ, H., RUBEŠOVÁ, K., PEKOVIĆ, M., VOLKMANNOVÁ, J., GRAF, M. (2019). Effects of cooling rate on the volume fraction of retained austenite in forgings from high-strength Mn-Si steels, Acta Mettalurgica Slovaca, Vol. 25, No. 2, pp. 93-100.
[4] HODINÁŘ, L., SVOBODOVÁ, J., HREN, I., CAIS, J., MICHNA, Š. (2019). The Manganese Influence on the AlSi12 Alloy Alfinal Bath Mechanical Properties Change, Manufacturing Technology, Vol. 19, No. 1, pp. 54-63.

[5] SEJČ, P., JAŠKO, P., BAXA, P., BELANOVÁ, J. (2017). Stability of $\mathrm{Ni} / \mathrm{TiB}_{2}$ coating on cucrzr Elekctrodes for resistance spot welding galvanized steeel sheet, Manufacturing Technology, Vol. 17, No. 4, pp. 570-576.

[6] PTÁČEK, L., JAŠKO. (1999). Nauka o materiálu II, pp. 350, ISBN 80-7204-130-4, Brno.

[7] ZÁBAVNÍK, V. Chemicko-tepelné zpracovanie kovov, pp. 141, Technická univerzita, Košice.

[8] MICHNA, S., TRPČEVSKÁ, J., NOVÁ, I. (2012). Strojírenská technologie, 1st ed., No. 4, pp. 337, ISBN 978-80-7414-501-8, Univerzita J.E. Purkyně, Ústí nad Labem.

[9] https://slideplayer.cz/slide/2327518/

[10] http://ime.fme.vutbr.cz/images/umvi/vyuka/struktura_a_vlastnosti_materialu/prednasky $/ 04 \% 20$ -

$\% 20$ Druhy $\% 20 \mathrm{a} \% 20$ zpusoby $\% 20$ TZ.ppt 